\title{
Partial purification and characterization of a soluble protein kinase from Leishmania donovani promastigotes
}

\author{
Chandana BanerJee and DwiJen Sarkar* \\ Leishmania Group \& Department of Cell Biology, Indian Institute of Chemical Biology, 4 Raja S.C. Mullick Road, \\ Jadavpur, Calcutta-700032, India
}

(Received 25 July 1989; revised 12 December 1989; accepted 19 February 1990)

\begin{abstract}
A soluble protein kinase from the promastigote form of the parasitic protozoon Leishmania donovani was partially purified using DEAE-cellulose, Sephadex G-200 and phosphocellulose columns. The enzyme preferentially utilized protamine as exogenous phosphate acceptor. The native molecular mass of the enzyme was about $85 \mathbf{~ k D a}$. $\mathbf{M g}^{2+}$ ions were essential for enzyme activity; other metal ions, e.g. $\mathrm{Ca}^{2+}, \mathrm{Co}^{2+}, \mathrm{Zn}^{2+}$ and $\mathrm{Mn}^{2+}$, could not substitute for $\mathrm{Mg}^{2+}$. cAMP, cGMP, $\mathrm{Ca}^{2+} /$ calmodulin and $\mathrm{Ca}^{2+} /$ phospholipid did not stimulate enzyme activity. The $\mathrm{pH}$ optimum of the enzyme was 7.0-7.5, and the temperature optimum $37^{\circ} \mathrm{C}$. The apparent $K_{\mathrm{m}}$ for ATP was $60 \mu \mathrm{M}$. Phosphoamino acid analysis revealed that the protein kinase transferred the $\gamma$-phosphate of ATP to serine residues in protamine. The thiol reagents $p$-hydroxymercuribenzoic acid, 5-5'-dithio-bis(2-nitrobenzoic acid) and $N$ ethylmaleimide inhibited enzyme activity; the inhibition by $p$-hydroxymercuribenzoic acid and $5-5^{\prime}$-dithio-bis(2nitrobenzoic acid) was reversed by dithiothreitol.
\end{abstract}

\section{Introduction}

Leishmania are characterized by existing in two main forms - as an amastigote when in the cells of the vertebrate host and as a promastigote in the gut of the insect vector. Leishmania donovani, the aetiological agent of visceral leishmaniasis (also known as kala-azar) replicates in mononuclear phagocytic cells of the spleen, liver, lymph glands and bone marrow and produces a chronic disease which usually results in death in untreated cases.

Phosphorylation/dephosphorylation has long been recognized as a process of reversible, covalent protein modification. These reactions are thought to serve a regulatory function in the short-term control of a variety of cellular processes. Protein kinases have been classified according to the specific effector molecules that directly interact with them and regulate their function. Thus distinct classes of protein kinases are known to exist whose actions depend upon second messengers-cAMP, cGMP, $\mathrm{Ca}^{2+} /$ calmodulin and $\mathrm{Ca}^{2+} /$ phospholipid. In addition, there is a group of protein kinases which are

Abbreviations: DTNB, 5,5'-dithio-bis(2-nitrobenzoic acid); NEM, $\mathrm{N}$-ethylmaleimide. apparently independent of control via specific regulatory effectors. Besides numerous reports describing protein kinases in animals, there are reports of protein kinase activity in protozoa (Majumder et al., 1973), fungi (Pall, 1981), plants (Keates, 1973) and bacteria (Rahmsdorf et al., 1974). Reports of protozoal protein kinases are few, but such enzymes have been characterized from Plasmodium berghei (Wiser et al., 1983; Wiser \& Schweiger, 1985), Trypanosoma brucei (Walter \& Opperdoes, 1982), $T$. gambiense and T. cruzi (Walter, 1976; Gomez et al., 1989). Das et al. (1986) characterized a cyclic-nucleotideindependent protein kinase in $L$. donovani. This enzyme is localized on the outer surface of the parasite and preferentially uses histone as exogenous phosphate acceptor. Berman (1988) recently isolated a protein kinase from $L$. mexicana promastigotes and amastigotes and compared it with the $L$. donovani enzymes reported by Das et al. (1986). Inosine analogues and their triphosphates compete with ATP for the enzyme. Gundersen \& Nelson (1987) demonstrated a novel $\mathrm{Ca}^{2+}$. dependent protein kinase from the ciliated protozoon Paramecium tetraurelia.

We have characterized and partially purified a soluble cyclic-nucleotide-independent protein kinase from $L$. donovani promastigotes and we report some of its properties in this paper. 


\section{Methods}

Materials. [ $\gamma^{-32}$ P]ATP [3000 Ci mmol $\left.{ }^{-1}\left(111 \mathrm{TBq}^{\mathrm{mmol}}{ }^{-1}\right)\right]$ was purchased from Bhaba Atomic Research Centre, Bombay, India. Sephadex G-200 and calmodulin were from Pharmacia. Mixed histones, protamine, casein, phosvitin, cAMP, cGMP, kemptide, PMSF, benzamidine. $\mathrm{HCl}$, ATP, diolein, phosphatidylinositol and $p$ hydroxymercuribenzoic acid were obtained from Sigma. DTNB and NEM were obtained from Pierce. All other chemicals were of analytical grade and were purchased from Merck.

Parasite. Promastigotes of Leishmania donovani (MHOM/ IN/1978/UR6), an Indian strain, highly subpassaged on modified Ray's blood-agar slants, were grown at $24-26^{\circ} \mathrm{C}$ for $72 \mathrm{~h}$ (Ray, 1932). The cells were harvested when at late exponential phase, washed three times in isotonic cold phosphate-buffered saline (10 mM-potassium phosphate, $150 \mathrm{~mm}-\mathrm{NaCl}$, pH 7.4) containing $0.5 \mathrm{~mm}-\mathrm{PMSF}, 1 \mathrm{~mm}-$ iodoacetic acid, $5 \mathrm{~mm}$-benzamidine. $\mathrm{HCl}$, and kept at $-20^{\circ} \mathrm{C}$ until use.

Protein kinase assay. Protein kinase activity was assayed routinely with protamine as the phosphate acceptor. The standard reaction mixture $(0.2 \mathrm{ml})$ contained $50 \mathrm{mM}$-Tris/maleate buffer, $\mathrm{pH} 7.0,20 \mathrm{mM}-$ $\mathrm{MgCl}_{2}, 0.25 \mathrm{mg}$ protamine, $150 \mu \mathrm{M}-\left[\gamma^{-32} \mathrm{P}\right] \mathrm{ATP}$ (80-100 c.p.m. $\mathrm{pmol}^{-1}$ ), $10 \mathrm{mM}$-DTT, $2.5 \mathrm{mg} \mathrm{BSA} \mathrm{ml}^{-1}$ and an appropriate amount of protein kinase and was incubated at $37^{\circ} \mathrm{C}$. After $10 \mathrm{~min}, 1 \mathrm{ml}$ ice-cold $10 \%(\mathrm{w} / \mathrm{v})$ trichloroacetic acid (TCA) was added and the mixture filtered through a glass microfibre filter paper (GF/C, Whatman) using a Millipore manifold apparatus fitted with a vacuum pump. The filter paper was washed twice with $5 \mathrm{ml}$ ice-cold $5 \%$ TCA and finally analysed for radioactivity as described by Rubin $e t$ al. (1974). The units of protein kinase activity were defined as the incorporation into protamine of $1 \mathrm{pmol}^{32} \mathrm{P}$ min-1 $^{-1}$ (except Table 1: $1 \mathrm{nmol} \mathrm{min}^{-1}$ ).

When mixed histones and phosvitin were used as substrate, reactions were terminated with $1 \mathrm{ml}$ ice-cold $10 \%$ TCA and phosphorylated products isolated as described above. The amount of ${ }^{32} \mathrm{P}$ incorporated into casein was measured as described by Hathaway \& Traugh (1983) after terminating the reaction by spotting $50 \mu \mathrm{l}$ of the assay mixture on to ET31 $(2 \times 2 \mathrm{~cm}$, Whatman) papers. When kemptide was used as substrate the reaction was terminated with $90 \mu$ glacial acetic acid. The phosphorylated kemptide was measured according to the method of De La Houssaye and Masaracchia (1983). Membrane-bound histone kinase activity was determined using a high concentration of mixed histones as phosphate acceptor as suggested by Das et al. (1986).

Purification of the protein kinase. Unless otherwise stated all operations were done at $2-4^{\circ} \mathrm{C}$

(a) Extraction. Frozen packed cells (about $10 \mathrm{ml}$ ) were suspended in $50 \mathrm{ml} 20 \mathrm{~mm}$-potassium phosphate buffer, $\mathrm{pH} 6.8$, containing $1 \mathrm{~mm}$ EGTA, $1 \mathrm{~mm}$-iodoacetic acid, $5 \mathrm{~mm}$-benzamidine. $\mathrm{HCl}, 10 \mathrm{~mm}-2-$ mercaptoethanol, $0.5 \mathrm{mM}-\mathrm{PMSF}, 0.02 \%$ sodium azide and $10 \%(\mathrm{v} / \mathrm{v})$ glycerol (buffer I). The resulting suspension was homogenized [15 strokes at 1200 r.p.m. in a Potter S homogenizer (Braun Instruments)] and sonicated $(45-60 \mathrm{~W})$ for $20 \mathrm{~s}$ on a Labsonic 2000 sonifier, with 1 min intervals between each sonication. The homogenate was centrifuged at $100000 \mathrm{~g}$ for $90 \mathrm{~min}$ and the supernatant used for further purification.

(b) DEAE-cellulose chromatography. The $\mathrm{pH}$ and conductivity of the supernatant was adjusted and the sample applied to a DE-52 DEAEcellulose column $(2.5 \times 20 \mathrm{~cm})$ pre-equilibrated with buffer I. The column was washed extensively with $300 \mathrm{ml}$ buffer $\mathrm{I}$ and the protein kinase was eluted with $500 \mathrm{ml}$ of a linear $(0-0.3 \mathrm{M}) \mathrm{NaCl}$ gradient in buffer I. Fractions (7 ml) of the eluate were collected. Fractions 24-30, which contained most of the protein kinase activity, were pooled and concentrated in an Amicon nitrogen pressure cell using a PM-30 membrane.

(c) Sephadex G-200 filtration. The concentrated pooled fractions from the DEAE-cellulose column were dialysed extensively against $20 \mathrm{mM}$ - potassium phosphate buffer, pH 6.8, containing $150 \mathrm{mM}-\mathrm{NaCl}$ (buffer II) for 16-18 $\mathrm{h}$. The dialysed sample was layered on to a Sephadex G-200 column $(1.6 \times 60 \mathrm{~cm})$ pre-equilibrated with buffer II. The sample was eluted with the same buffer and fractions (about $8 \mathrm{ml}$ ) were collected. Fractions $8-12$, which contained the protein kinase activity were pooled and concentrated.

(d) Phosphocellulose column chromatography. The pooled fractions from the Sephadex G-200 filtration were desalted through Sephadex G-25 pre-equilibrated with 20 mM-potassium phosphate buffer, $\mathrm{pH} 6 \cdot 0$, containing 1 mM-EGTA, 1 mm-iodoacetic acid, 5 mm-benzamidine. $\mathrm{HCl}, 10 \mathrm{mM}-2$-mercaptoethanol, $0.5 \mathrm{~mm}$-PMSF, $0.02 \%$ sodium azide and $10 \%(\mathrm{v} / \mathrm{v})$ glycerol (buffer III), and the desalted material was applied to a phosphocellulose column $(0.9 \times 15 \mathrm{~cm})$. The column was washed extensively and the protein kinase was eluted with $100 \mathrm{ml}$ of a linear $(0-0.7 \mathrm{M}) \mathrm{NaCl}$ gradient in buffer III. Fractions of about $3 \mathrm{ml}$ were collected. Fractions $8-10$, which contained most of the protein kinase activity, were pooled and dialysed extensively against buffer I containing $50 \%(\mathrm{v} / \mathrm{v})$ glycerol. This partially purified protein kinase preparation lost less than $5 \%$ of its activity when stord for 2-3 months at $0-4{ }^{\circ} \mathrm{C}$

Gel filtration. This was done on a Sephadex G-200 $(1 \cdot 6 \times 60 \mathrm{~cm})$ column, pre-equilibrated with buffer II. A sample $(2 \mathrm{ml})$ of the purified protein kinase preparation was applied and the column was run as described above. The column was standardized with aldolase, BSA, ovalbumin and chymotrypsinogen A. Dextran blue and Orange $G$ were used to determine the void volume and total column volume, respectively. Molecular mass was determined according to the method of Andrews (1964).

$S D S-P A G E$. Electrophoresis in $10 \%(\mathrm{w} / \mathrm{v})$ polyacrylamide slab gels containing $0.1 \%$ SDS was done by the method of Laemmli (1970). Gels were fixed, stained and destained according to Fairbanks et al. (1971). Estimates of subunit molecular masses were obtained from plots of log molecular mass versus relative mobilities of six standard proteins: albumin (66 kDa), ovalbumin ( $45 \mathrm{kDa})$, glyceraldehyde-3-phosphate dehydrogenase $(36 \mathrm{kDa})$, carbonic anhydrase $(29 \mathrm{kDa})$, trypsinogen $(24$ $\mathrm{kDa}$ ) and lactalbumin $(14.2 \mathrm{kDa})$.

Phosphoamino acid analysis. Protamine $(250 \mu \mathrm{g})$ was phosphorylated in the presence of leishmanial protein kinase under standard assay condition except that the incubation time was extended to $1 \mathrm{~h}$. The ${ }^{32} \mathrm{P}$ labelled product was precipitated with $15 \%(\mathrm{w} / \mathrm{v})$ TCA. The precipitate was washed twice with $1: 1(\mathrm{v} / \mathrm{v})$ acetone/diethyl ether, dried and hydrolysed in $0.5 \mathrm{ml} 6 \mathrm{M}-\mathrm{HCl}$ at $110^{\circ} \mathrm{C}$ for $4 \mathrm{~h}$. The hydrolysate was air-dried and dissolved in $0.1 \mathrm{ml}$ formic acid/acetic $\mathrm{acid} / \mathrm{H}_{2} \mathrm{O}(25: 78: 897$, by vol. $) \mathrm{pH} 1.9$. Samples $(10 \mu \mathrm{l})$ were mixed with authentic internal standards (phosphoserine, phosphothreonine and phosphotyrosine), applied to the cathode edge of a cellulose thin-layer sheet (Eastman 13250) and electrophoresed at $450 \mathrm{~V}$ for $90 \mathrm{~min}$ in a $\mathrm{pH}$ 3.5 buffer system (acetic acid/pyridine/ $\mathrm{H}_{2} \mathrm{O} ; 50: 5: 945$, by vol.) (Cooper et al., 1983). Radioactive spots were located by radioautography, whereas phosphoamino acid markers were visualized by spraying with ninhydrin reagent.

Protein determination. Protein concentration was estimated by the method of Bradford (1976) with BSA as standard.

\section{Results}

\section{Purification of the protein kinase}

The results of the purification are summarized in Table 1. About $0.9 \mathrm{mg}$ of partially purified enzyme was obtained from $10 \mathrm{ml}$ of frozen packed cells. The 
Table 1. Purification of protein kinase from L. donovani promastigotes

The units of protein kinase activity are nmol ${ }^{32} \mathrm{P}$ incorporated $\min ^{-1}$ using protamine as substrate. The data are representative of three experiments.

\begin{tabular}{|c|c|c|c|c|c|c|}
\hline $\begin{array}{l}\text { Purification } \\
\text { step }\end{array}$ & $\begin{array}{l}\text { Vol. } \\
(\mathrm{ml})\end{array}$ & $\begin{array}{c}\text { Protein } \\
\left(\mathrm{mg} \mathrm{ml}^{-1}\right)\end{array}$ & $\begin{array}{c}\text { Specific } \\
\text { activity } \\
\text { [units }(\text { mg protein })^{-1} \text { ] }\end{array}$ & $\begin{array}{l}\text { Total } \\
\text { activity } \\
\text { (units) }\end{array}$ & $\begin{array}{l}\text { Purification } \\
\text { (-fold) }\end{array}$ & $\begin{array}{l}\text { Yield } \\
(\%)\end{array}$ \\
\hline $\begin{array}{l}100000 \mathrm{~g} \\
\text { supernatant }\end{array}$ & 80 & 3.95 & $4 \cdot 3$ & 1359 & 1 & 100 \\
\hline DEAE-Cellulose & $6 \cdot 0$ & $5 \cdot 10$ & $23 \cdot 8$ & 753 & $5 \cdot 5$ & 55 \\
\hline Sephadex G-200 & $15 \cdot 0$ & 0.68 & $50 \cdot 0$ & 510 & $10 \cdot 8$ & 48 \\
\hline Phosphocellulose & $6 \cdot 0$ & $0 \cdot 15$ & 390 & 351 & 91 & 26 \\
\hline
\end{tabular}

procedure resulted in a 91-fold purification of the enzyme with a recovery of $26 \%$. This enzyme preparation was stable for at least 3 months when stored in buffer I containing $50 \%$ glycerol at $0-4{ }^{\circ} \mathrm{C}$. Fig. 1 shows the chromatographic profile of the protein kinase as eluted from the DE-52 column, with a major peak of activity at 40-70 mM- $\mathrm{NaCl}$. When this preparation was subjected to gel filtration through a Sephadex G-200 column, a single relatively sharp and symmetrical peak was obtained (Fig. 2), indicative of a single protein kinase. The enzyme preparation eluted from the Sephadex column was further chromatographed through a phosphocellulose column (Fig. 3). A single peak of protein kinase was eluted from this column at 110-200 mM$\mathrm{NaCl}$. The purity of this enzyme was examined by SDSPAGE. Staining with Coomassie Blue revealed at least three bands, with molecular masses of $53 \mathrm{kDa}, 48 \mathrm{kDa}$ and $32 \mathrm{kDa}$, with the $53 \mathrm{kDa}$ protein the most prominent (Fig. 4).

During the purification of the protein kinase, we also looked for the histone kinase activity described by Das $e t$ al. (1986). We found that most of the histone kinase activity remained in the $100000 \mathrm{~g}$ pellet (see Methods) indicating that this activity was mostly membranebound.

\section{Properties of the protein kinase}

The partially purified leishmanial protein kinase eluted from the phosphocellulose column was used to characterize some of the physicochemical and kinetic properties of the enzyme.

Size. The protein kinase eluted from the Sephadex G-200 column between aldolase and BSA, at an apparent molecular mass of $85 \mathrm{kDa}$.

Substrate specificity. A variety of commonly used protein substrates, namely protamine, mixed histones, phosvitin, dephosphorylated casein and the synthetic peptide kemptide (Leu-Arg-Arg-Ala-Ser-Leu-Gly) were compared in the standard protein kinase assay (Table 2). Highest activity was observed with protamine as exogenous phosphate acceptor, with, surprisingly, kemp-

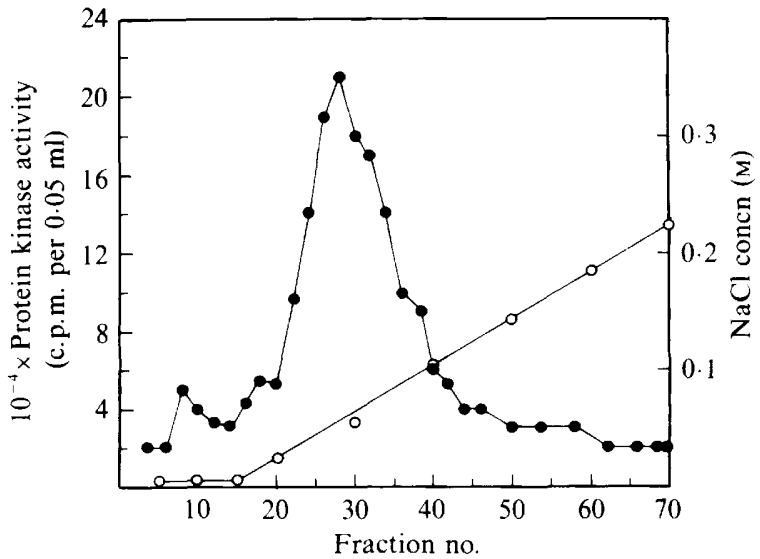

Fig. 1. Chromatography of $L$. donovani cell extract on a $2.5 \times 20 \mathrm{~cm}$ DE-52 DEAE-cellulose column. The $100000 \mathrm{~g}$ supernatant from the $L$. donovani extract was diluted, adsorbed on to the DEAE cellulose column and eluted with $500 \mathrm{ml}$ of a linear $(0-0.3 \mathrm{M}) \mathrm{NaCl}$ gradient in buffer I, pH 6.8; fractions of $7 \mathrm{ml}$ were collected. The experiment was done three times; values shown are from a typical experiment (the other experiments showed similar trends). Protein kinase activity; $\bigcirc$, $\mathrm{NaCl}$ concn.

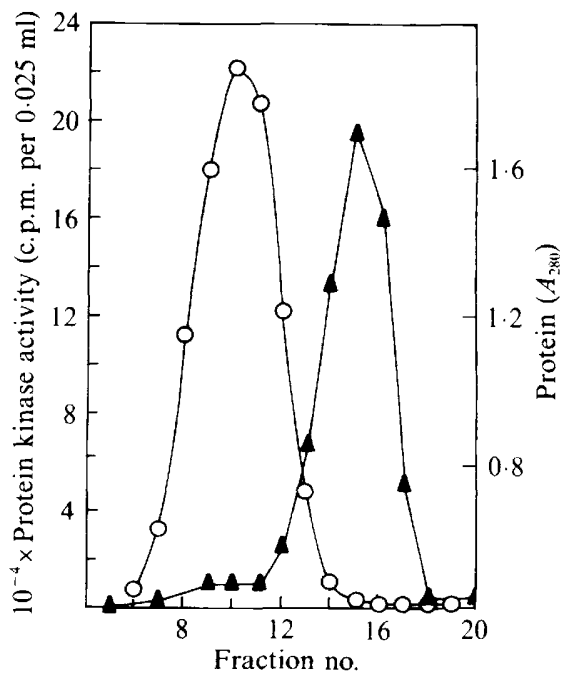

Fig. 2. Gel-filtration chromatography of $L$. donovani protein kinase on Sephadex G-200. The DE-52 eluate (Fig. 1) containing the protein kinase activity was concentrated and dialysed, and applied to a Sephadex G200 column $(1.6 \times 60 \mathrm{~cm})$; fractions of about $8 \mathrm{ml}$ were collected. The experiment was done three times; values shown are from a typical experiment (the other experiments showed similar trends). $O$, Protein kinase activity; $\mathbf{A}$, protein $\left(A_{280}\right)$. 


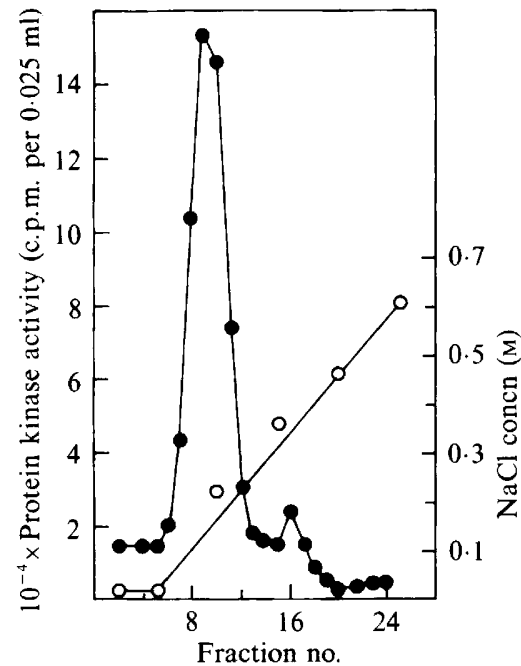

Fig. 3. Chromatography of $L$. donovani protein kinase on phosphocellulose. Fractions from the Sephadex column (Fig. 2) that contained protein kinase activity were pooled and desalted, and were then applied to a $0.9 \times 15 \mathrm{~cm}$ phosphocellulose column. Protein kinase activity was eluted with a linear $(0-0.7 \mathrm{M}) \mathrm{NaCl}$ gradient in buffer III; fractions of $3 \mathrm{ml}$ were collected. The experiment was done three times; values shown are from a typical experiment (the other experiments showed similar trends). Protein kinase activity; $\mathrm{O}, \mathrm{NaCl}$ concn.

\section{Table 2. Substrate specificity of $L$. donovani protein kinase}

The assay was done with the specified amount of acceptor in a $0.2 \mathrm{ml}$ assay mixture as described in Methods. Values are means $\pm S D$ of four sets of experiments.

\begin{tabular}{|c|c|}
\hline Substrate & $\begin{array}{c}\text { Protein } \\
\text { kinase activity } \\
\left(\text { pmol }{ }^{32} \mathrm{P}\right. \\
\left.\text { transferred } \text { min }^{-1}\right)\end{array}$ \\
\hline Protamine sulphate $\left(1.25 \mathrm{mg} \mathrm{ml}^{-1}\right)$ & $70 \cdot 0 \pm 3 \cdot 5$ \\
\hline Kemptide $\left(0.25 \mathrm{mg} \mathrm{ml}^{-1}\right)$ & $19 \cdot 5 \pm 0.8$ \\
\hline Mixed histone $\left(1.25 \mathrm{mg} \mathrm{ml}^{-1}\right)$ & $11 \cdot 0 \pm 0 \cdot 5$ \\
\hline Phosvitin $\left(1.25 \mathrm{mg} \mathrm{ml}^{-1}\right)$ & $5 \cdot 0 \pm 0 \cdot 2$ \\
\hline Casein (dephosphorylated) $\left(1.25 \mathrm{mg} \mathrm{m}^{-1}\right)$ & $5 \cdot 0+0.4$ \\
\hline
\end{tabular}

tide as the second best acceptor. Phosvitin and dephosphorylated casein were poor substrates.

When protamine phosphorylated by the protein kinase was subjected to acid hydrolysis and the phosphoamino acids separated on cellulose thin-layer plates, a considerable amount of the radioactivity ran with the phosphoserine standard (Fig. 5). We conclude that the protein kinase transfers the $\gamma$-phosphate of ATP to serine residues in protamine.

Metal-ion requirements. Omission of $\mathrm{Mg}^{2+}$ ions from the assay medium drastically reduced enzyme activity (Table 3). Activity was highest at $15-20 \mathrm{mM}-\mathrm{MgCl}_{2}$, but concentrations higher than $30 \mathrm{~mm}$ were inhibitory (not
1

2

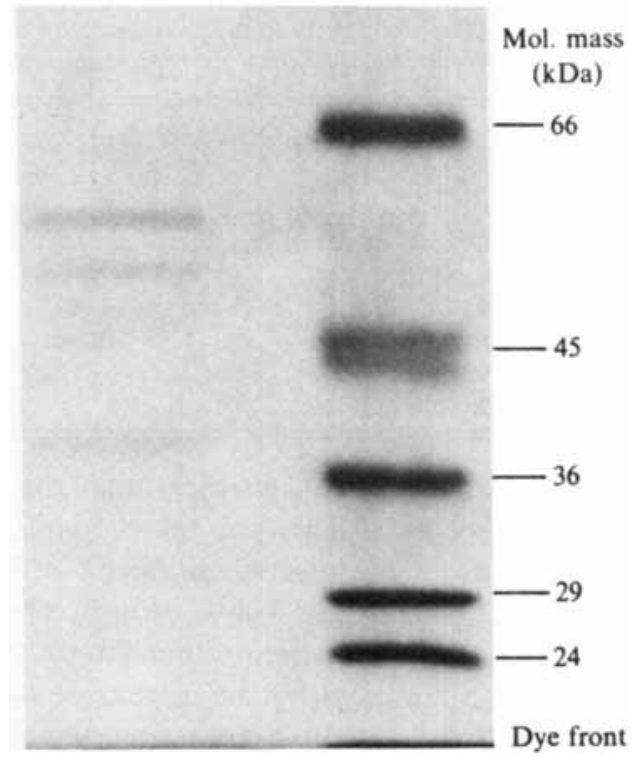

Fig. 4. SDS-PAGE of the partially purified $L$. donovani protein kinase. Approximately $6 \mu \mathrm{g}$ of the final preparation from the phosphocellulose column (Fig. 3) was subjected to SDS-PAGE (10\%, w/v, acrylamide) and stained with Coomassie Brilliant Blue (lane 1). Lane 2, molecular mass standards as described in Methods (lactalbumin ran with the dye front).

shown). $\mathrm{Mn}^{2+}$ had a slightly stimulatory effect on enzyme activity, but divalent metal ions, e.g. $\mathrm{Ca}^{2+}, \mathrm{Co}^{2+}$ and $\mathrm{Zn}^{2+}$, were inhibitory. Addition of low concentrations of $\mathrm{NaCl}$ had no effect on enzyme activity, but 40 $\mathrm{mM}-\mathrm{NaCl}$ was slightly inhibitory. This is in contrast to the observation of Das et al. (1986), who found that omission of $\mathrm{NaCl}$ from the standard assay reduced the protein kinase activity by about $80 \%$.

Effector molecules. None of the following potential effectors had any effect on protein kinase activity: cAMP or cGMP (0.01 and $0.05 \mathrm{mM})$; $\mathrm{Ca}^{2+}(0.2 \mathrm{mM})$; $\mathrm{Ca}^{2+}(0.2 \mathrm{mM}) /$ calmodulin $(1.8 \mu \mathrm{g})$; diolein $(15 \mu \mathrm{M})$; phosphatidylinositol $(10 \mu \mathrm{g})$; phosphatidylinositol $(10$ $\mu \mathrm{g}) / \mathrm{Ca}^{2+}(10 \mu \mathrm{M}) /$ diolein $(15 \mu \mathrm{M})$ (all tested on $0.3 \mu \mathrm{g}$ protein kinase in the standard assay).

Effect of thiol reagents. DTNB, p-hydroxymercuribenzoate and NEM all inhibited the protein kinase (Table 4). Inhibition by DTNB and $p$-hydroxymercuribenzoic acid could be reversed by DTT, whereas inhibition by NEM was irreversible.

ATP requirement. The effect of ATP concentration $(0 \cdot 005-0 \cdot 15 \mathrm{mM})$ on kinase activity was examined. A Lineweaver-Burk plot of the data (not shown) indicated an apparent $K_{\mathrm{m}}$ for ATP of $60 \mu \mathrm{M}$.

Effect of $p H$. The $\mathrm{pH}$ optimum of the protein kinase using protamine as substrate was $\mathrm{pH} 7 \cdot 0-7 \cdot 5$. 


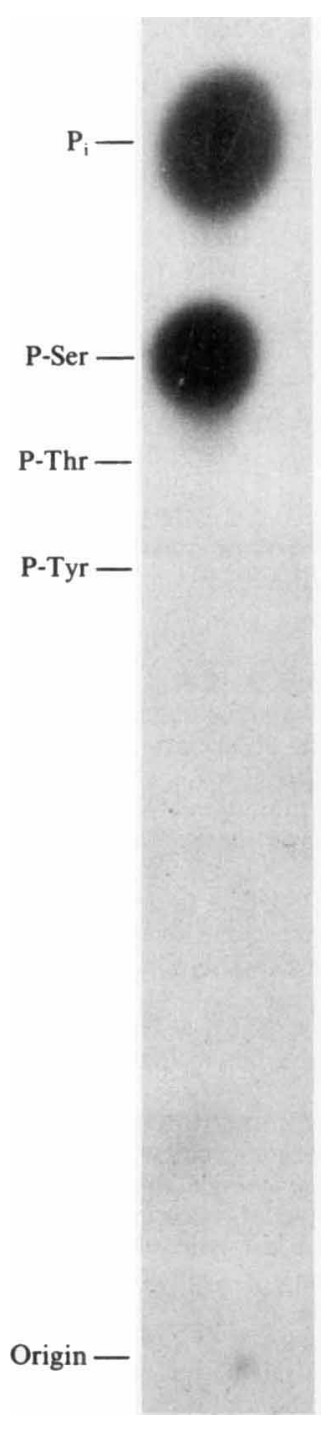

Fig. 5. Identification of the phosphorylated amino acid. Protamine was phosphorylated and the ${ }^{32} \mathrm{P}$-labelled product analysed by cellulose thinlayer chromatography, as described in Methods. ${ }^{32} \mathrm{P}$ was detected by autoradiography. The positions of authentic internal standards are indicated (P-Ser, phosphoserine; P-Thr, phosphothreonine; P-Tyr, phosphotyrosine).

Effect of temperature. Protein kinase activity was highest at $37^{\circ} \mathrm{C}$; most of the activity was lost after heating to $50{ }^{\circ} \mathrm{C}$.

\section{Localization of protein kinase activities}

The protamine-utilizing protein kinase activity described in this paper could be distinguished from the histone-utilizing protein kinase activity described by Das et al. (1986) by exposing leishmanial promastigote cells to controlled hypotonic shock. For this purpose, we adopted a procedure recently developed in our laboratory by Sarkar (1989). When about $10^{8}$ intact promastigote cells were suspended $(1: 50)$ in $5 \mathrm{~mm}$-Tris/ $\mathrm{HCl}$ buffer, $\mathrm{pH} 7 \cdot 4$, with gentle shaking, there was a rapid and nearly complete $(>95 \%)$ release of the cytoplasmic marker enzymes glucose-6-phosphate dehydrogenase and UDPglucose-4-epimerase within $10 \mathrm{~min}$. In contrast, the washed, pelleted cell ghosts, which kept their original polarity (Sarkar, 1989) retained almost complete activity of the plasma-membrane marker enzymes 3'-nucleotidase and acid phosphatase, and nearly $50 \%$ of the activity of the kinetoplast-mitochondria membranemarker enzyme succinate dehydrogenase. Under the same conditions, more than $90 \%$ of protamine kinase activity was released into the supernatant within $10 \mathrm{~min}$, whereas more than $95 \%$ of the histone kinase activity remained with the pelleted ghost preparation at the end of this period. This clearly indicates that the protamine kinase is a soluble enzyme whereas histone kinase is membrane-associated.

\section{Discussion}

Our results show that a protein kinase is present in the soluble fraction of $L$. donovani promastigotes that is capable of phosphorylating protamine and, less efficiently, mixed histones, casein and phosvitin. The activity of this protein kinase is not regulated by cAMP, cGMP, $\mathrm{Ca}^{2+} /$ calmodulin or $\mathrm{Ca}^{2+} /$ phospholipid.

Das et al. (1986) described an $L$. donovani protein kinase that preferentially phosphorylates histone. This enzyme has a number of properties in common with the protein kinase described in the present paper; both have similar $\mathrm{pH}$ optima, $\mathrm{Mg}^{2+}$ requirements and temperature optima, both phosphorylate exclusively serine residues of their protein substrates, and neither is stimulated by cAMP, $\mathrm{Ca}^{2+} /$ calmodulin etc. The enzymes differ in their $K_{\mathrm{m}}$ for ATP, substrate requirement, molecular mass and $\mathrm{NaCl}$ requirement, but the most striking distinction between the two is their localization. The histone kinase activity described by Das et al. (1986) is tightly bound to the outer surface of the parasite and can be released only by repeated freezing/thawing and/or treatment with bile salts, whereas the protamine kinase reported in the present study is soluble, and easily released by controlled hypotonic shock.

The protein kinase characterised in this study was inhibited by reagents that react with thiol groups. Inhibition by $p$-hydroxymercuribenzoic acid and DTNB was dose-dependent and could be reversed by DTT, whereas inhibition by NEM was irreversible. This suggests that the cysteine residue(s) in the protein kinase might be located at or near the active site of the enzyme. This is in agreement with the observation made by 
Table 3. Effect of metal ions on L. donovani protein kinase activity

Protein kinase activity was assayed as described in Methods in the presence of the metal ion(s) indicated (added as the chloride). The results are representative of two experiments done in duplicate.

\begin{tabular}{|c|c|c|c|c|c|}
\hline $\begin{array}{c}\text { Metal } \\
\text { ion }\end{array}$ & $\begin{array}{l}\text { Concn } \\
\text { (mM) }\end{array}$ & $\begin{array}{c}\text { Protein kinase } \\
\text { activity (pmol }{ }^{32} \mathrm{P} \\
\left.\text { transferred } \text { min }^{-1}\right)\end{array}$ & $\begin{array}{l}\text { Metal } \\
\text { ion }\end{array}$ & $\begin{array}{c}\text { Concn } \\
(\mathrm{mM})\end{array}$ & $\begin{array}{c}\text { Protein kinase } \\
\text { activity (pmol }{ }^{32} \mathrm{P} \\
\text { transferred } \mathrm{min}^{-1} \text { ) }\end{array}$ \\
\hline None & - & $2 \cdot 5$ & $\mathrm{Ca}^{2+}$ & 20 & 0.2 \\
\hline $\mathbf{M g}^{2+}$ & 20 & $22 \cdot 0$ & $\mathrm{Ca}^{2+}$ & 40 & ND \\
\hline $\mathrm{Mn}^{2+}$ & 20 & $4 \cdot 2$ & $\mathrm{Zn}^{2+}$ & 20 & ND \\
\hline $\mathrm{Mn}^{2+}$ & 80 & $4 \cdot 1$ & $\mathrm{Zn}^{2+}$ & 40 & ND \\
\hline $\mathrm{Co}^{2+}$ & 20 & ND & $\mathrm{Na}^{+}$ & 10 & $20 \cdot 9^{*}$ \\
\hline $\mathrm{Co}^{2+}$ & 40 & 0.9 & $\mathrm{Na}^{+}$ & 40 & $16.9 *$ \\
\hline
\end{tabular}

ND, No protein kinase activity detected (i.e. $<0.01 \mathrm{pmol}^{32} \mathrm{P}$ transferred $\mathrm{min}^{-1}$ ).

${ }^{*} \mathrm{Mg}^{2+}(20 \mathrm{mM})$ was also present.

Table 4. Effect of thiol reagents on L. donovani protein kinase activity

\begin{tabular}{|c|c|c|c|}
\hline \multirow[b]{2}{*}{$\begin{array}{l}\text { Thiol } \\
\text { reagent }\end{array}$} & \multirow[b]{2}{*}{$\begin{array}{c}\text { Concn } \\
(\mathrm{mM})\end{array}$} & \multicolumn{2}{|c|}{$\begin{array}{c}\text { Protein kinase activity } \\
\left(\text { pmol }{ }^{32} \mathrm{P} \text { transferred } \text { min }^{-1}\right)\end{array}$} \\
\hline & & -DTT & $\begin{array}{c}+\mathrm{DTT} \\
(10 \mathrm{mM})\end{array}$ \\
\hline None & & $15 \cdot 6 \pm 2 \cdot 1$ & $17 \cdot 0 \pm 2 \cdot 3$ \\
\hline $\begin{array}{l}p \text {-Hydroxymercuri- } \\
\text { benzoic acid }\end{array}$ & $\begin{array}{l}0 \cdot 01 \\
0 \cdot 05 \\
0 \cdot 10\end{array}$ & $\begin{array}{r}11.2 \pm 1.6 \\
6.3 \pm 0.9 \\
3.3 \pm 0.5\end{array}$ & $\begin{array}{l}17 \cdot 0 \pm 1 \cdot 6 \\
16.4 \pm 1 \cdot 1 \\
16.9 \pm 1 \cdot 1\end{array}$ \\
\hline DTNB & $\begin{array}{l}0 \cdot 10 \\
0 \cdot 20\end{array}$ & $\begin{array}{r}11 \cdot 0 \pm 2 \cdot 0 \\
4 \cdot 1 \pm 0 \cdot 5\end{array}$ & $\begin{array}{l}21 \cdot 3 \pm 2 \cdot 5 \\
20 \cdot 4 \pm 2 \cdot 5\end{array}$ \\
\hline NEM & $0 \cdot 40$ & $1 \cdot 1 \pm 0 \cdot 2$ & $2.4 \pm 0.5$ \\
\hline
\end{tabular}

Bechtel et al. (1977) for the catalytic subunit of soluble cAMP-dependent protein kinase of muscle.

The role of $L$. donovani protein kinase is not yet known. It is possible that it participates in the phosphorylation of the intracellular protein(s) required for growth and differentiation. It will be of interest to discover the physiological substrate(s) of this protein kinase and whether phosphorylation of this substrate(s) has any effect on the transformation process. Such questions will be addressed once the protein kinase has been isolated in a pure form.

We wish to acknowledge the Director of this Institute for providing a Senior Research Fellowship supported by an institutional grant under the Director's quota to one of us (C. B.). We also acknowledge Mr S. K. Chaudhuri for typing, Mr D. D. Banerjee for photography and $\mathrm{Mr} \mathrm{H}$. N. Datta and Mr S. Sahu for artwork. The work was partly supported by UNDP, IND/87/018/A/99.

\section{References}

ANDREws, P. (1964). Estimation of the molecular weight of proteins by Sephadex gel-filtration. Biochemical Journal 91, 222-233.
Bechtel, P. J., Beavo, J. A. \& Krebs, E. G. (1977). Purification and characterization of catalytic subunit of skeletal muscle adenosine $3^{\prime}: 5^{\prime}$ monophosphate-dependent protein kinase. Journal of Biological Chemistry 252, 2691-2697.

BERMAN, J. D. (1988). Inhibition of leishmanial protein kinase by antileishmanial drugs. American Journal of Tropical Medicine and Hygiene 38, 298-303.

BRADFORD, M. M. (1976). A rapid and sensitive method for the quantitation of microgram quantities of protein utilizing the principle of protein-dye binding. Analytical Biochemistry 72, 248-256.

Cooper, J. A., Sefton, B. M. \& Hunter, T. (1983). Detection and quantification of phosphotyrosine in proteins. Methods in Enzymo$\log y$ 99, 387-402.

Das, S., Saha, A. K., Mukhopadhyay, N. K. \& Glew, R. W. (1986). A cyclic nucleotide-independent protein kinase in Leishmania donovani. Biochemical Journal 240, 641-649.

De La Houssaye, B. A. \& Masaracchia, R. A. (1983). Standardization of the assay for the catalytic subunit of cyclic AMP-dependent protein kinase using a synthetic peptide substrate. Analytical Biochemistry 128, 54-59.

Fairbanks, G., Steck, T. L. \& Wallach, D. F. H. (1971). Electrophoretic analysis of the major polypeptides of the human erythrocyte membrane. Biochemistry 10, 2606-2617.

Gomez, M. L., Erijman, L., Arauzo, S., Torres, H. N. \& TéllezINón, M. T. (1989). Protein kinase C in Trypanosoma cruzi epimastigote forms: partial purification and characterization. Molecular and Biochemical Parasitology 36, 101-108.

Gundersen, R. E. \& Nelson, D. L. (1987). A novel $\mathrm{Ca}^{2+}$-dependent protein kinase from Paramecium tetraurelia. Journal of Biological Chemistry 262, 4602-4609.

Hathway, G. M. \& Traugh, J. A. (1983). Casein kinase II. Methods in Enzymology 99, 317-331.

KeAtES, R. A. B. (1973). Cyclic nucleotide-independent protein kinase from pea shoots. Biochemical and Biophysical Research Communications 54, 655-661.

LAEMMLI, U. K. (1970). Cleavage of structural proteins during the assembly of the head of bacteriophage T4. Nature, London 227, 680685.

Majumder, G. C., Shrago, E. \& Elson, C. E. (1975). Changes in cyclic AMP dependent protein kinase activity in Tetrahymena pyriformis during the growth cycle. Biochimica et Biophysica Acta 384, 399-412.

PaLL, M. L. (1981). Adenosine 3'-5'-phosphate in fungi. Microbiological Reviews 45, 462-480.

Rahmsdorf, H. J., Pai, S. H., Ponta, H., Herrlich, R. R., JR, SCHWEIGER, M. \& STUdieR, F. W. (1974). Protein kinase induction in Escherichia coli by bacteriophage $\mathrm{T}_{7}$. Proceedings of the National Academy of Sciences of the United States of America 71, 586-589.

RAY, J. C. (1932). Cultivation of various Leishmania parasites on solid medium. Indian Journal of Medical Research 20, 355-357. 
Rubin, C. S., Erlichman, J. \& Rosen, O. M. (1974). Cyclic AMPdependent protein kinase from bovine heart muscle. Methods in Enzymology 38, 308-315.

SARKAR, S. (1989). Biochemical studies on some aspects of Leishmania donovani promastigote membrane. $\mathrm{PhD}$ thesis, Jadavpur University, Calcutta, India.

WALTER, R. D. (1976). Nucleoside-dependent protein kinase from Trypanosoma gambiense. Biochimica et Biophysica Acta 429, 137-146.

W ALTER, R. D. \& OPPERDOES, F. R. (1982). Subcellular distribution of adenylate cyclase, cyclic AMP-phosphodiesterase, protein kinase and phosphoprotein phosphatase in Trypanosoma brucei. Molecular and Biochemical Parasitology 6, 287-295.
WISER, M. F. \& SCHWEIGER, H. G. (1985). Cytosolic protein kinase activity associated with the maturation of the malaria parasite Plasmodium berghei. Molecular and Biochemical Parasitology 17, 179-189.

Wiser, M. F., EATON, J. W. \& ShepPard, J. R. (1983). A plasmodium protein kinase that is developmentally regulated, stimulated by spermine, and inhibited by quercetin. In Molecular Biology of HostParasite Interactions, pp. 7-16. Edited by N. Agabian \& H. Eiser. New York: Alan R. Liss. 